\title{
The Use of a Single Pulse of Intravenous Methylprednisolone in the Treatment of Corneal Graft Rejection. A Preliminary Report.
}

\author{
JOHN C. HILL, ${ }^{*}$ RICHARD MASKE, ${ }^{*}$ and PETER G. WATSON** \\ Cape Town, South Africa and Cambridge
}

\begin{abstract}
Summary
In corneal graft rejection, rapid reversal of the rejection process is necessary to minimise endothelial cell loss. Ten consecutive patients with acute endothelial rejection were treated with a single $500 \mathrm{mg}$ pulse of methylprednisolone intravenously and topical prednisolone $1 \%$ drops hourly. The rejection episode was successfully reversed in eight $(80 \%)$ of the 10 grafts. This preliminary trial indicates that corticosteroid pulse therapy may be beneficial in the management of severe corneal graft rejection with the advantage of avoiding prolonged oral corticosteroid therapy.
\end{abstract}

Corneal graft rejection is now the commonest cause of graft failure after the immediate postoperative period. ${ }^{1,2}$ Khodadoust and Silverstein $^{3}$ have shown that all three layers of the cornea can be rejected, either alone or in combination. The endothelium is the most important layer to be affected by rejection. Endothelial cells are lost at the time of surgery and during the first two to three years as cells migrate to replace cells lost at the edge of the graft during surgery. ${ }^{4}$ During a rejection episode large numbers of endothelial cells are destroyed $^{5}$ and even if the rejection process is reversed sufficient cells to maintain graft clarity may not survive." A rejection episode should therefore be reversed as quickly as possible to preserve maximal numbers of endothelial cells. ${ }^{7}$

Corticosteroids remain the mainstay in the treatment of graft rejection. Although some authors suggest that only topical corticosteroid drops should be used, ${ }^{8.9}$ others treat the more severe rejection episodes involving the endothelium with systemic steroids and/or subconjunctival steroids..$^{26.10}$ Allograft reactions have been defined as definite, probable and possible depending on the clinical findings. "We have found that the use of topical corticosteroids alone in cases of definite and probable rejection has a low success rate $(39 \%)$ in reversing graft rejection (unpublished data). Very little data exists regarding the success of specific regimens for graft rejection; studies that used different routes of corticosteroids depending on the severity of the immune reaction quote success rates of $50-76 \%$ in reversing the rejection process. ${ }^{1.10 .12-1+}$ In a recent study Boisjoly et al. ${ }^{9}$ reported that 17 of 23 grafts $(73.9 \%)$ that developed a single episode of endothelial rejection failed when only topical corticosteroids were used. Our poor results using topical corticosteroids alone led us to modify our treatment regimen for cases of definite

From: Departments of Ophthalmology, Groote Schuur Hospital and University of Cape Town, ${ }^{*}$ Addenbrooke Hospital, Cambridge.**

Correspondence to: Dr. John C. Hill, Department of Ophthalmology, Medical School. University of Cape Town, Cape Town, South Africa. 
and probable rejection: oral prednisone 60 $80 \mathrm{mg}$ daily (depending on body weight) is given in addition to hourly prednisolone acetate $1 \%$ drops. Medication is tapered off after two weeks or before if the graft begins to recover, the systemic prednisone is usually stopped by six to eight weeks. Grafts wtih epithelial rejection or stromal infiltrates with no graft swelling continue to be treated with topical therapy alone.

The use of pulsed corticosteroid therapy is gaining acceptance in other fields of medicine and has been used in the management of ocular inflammation ${ }^{15.16}$ and in renal transplant rejection. ${ }^{17}$ A single intravenous dose of $125 \mathrm{mg}$ methylprednisolone sodium has been advocated in the management of severe graft rejection. ${ }^{18}$ Currently larger doses of corticosteroid are being used in single dose pulse therapy for other conditions, ${ }^{15-17}$ and we considered that similar therapy could have a place in corneal graft rejection to alleviate the need for prolonged oral doses of systemic corticosteroids. A preliminary study was therefore undertaken to assess the efficacy of this type of therapy in corneal graft rejection.

\section{Patients and Methods}

Ten consecutive adult patients presenting with endothelial rejection were entered into the trial; all gave informed consent prior to participation. Endothelial rejection was diagnosed when an eye with a previously clear, thin graft became inflamed with; flare and cells in the anterior chamber, keratic precipitates limited to the donor endothelium, and thickening of the graft either diffusely (probable rejection $)^{11}$ or in the form of an advancing rejection line (definite rejection). ${ }^{1}$ All patients were treated with hourly prednisolone acetate $1 \%$ drops while awake and a single intravenous injection of methylprednisolone $500 \mathrm{mg}$. The clinical details are shown in Table I; five males and 5 females were included in the study, with a mean age of 51.4 years (range 18-68). Of the six patients who had had previous grafts, two had had three grafts and one patient four previous grafts. Seven patients had vascularisation of the host cornea prior to grafting. The interval from the onset of rejection to treatment ranged from four days to three weeks. Three patients had a definite endothelial rejection line and the remaining 7 had diffuse endothelial rejection. The effects of the treatment were monitored by assessing the improvement in clinical signs and graft clarity and by the measurement of central graft thickness by ultrasonic pachymetry. A full blood and differential count was performed prior to treatment and repeated daily for three days.

\section{Results}

In eight $(80 \%)$ of the 10 grafts the rejection episode reversed and the graft became clear. The thickness of the central cornea during the

Table I Clinical details

\begin{tabular}{|c|c|c|c|c|c|c|c|}
\hline $\begin{array}{c}\text { Patient } \\
\text { no }\end{array}$ & Sex & Age & Diagnosis & $\begin{array}{l}\text { Vascularisation } \\
\text { (pre-operative) }\end{array}$ & $\begin{array}{l}\text { Previous } \\
\text { grafts }\end{array}$ & $\begin{array}{l}\text { Delay between } \\
\text { onset and } \\
\text { treatment of } \\
\text { rejection }\end{array}$ & Outcome \\
\hline 1 & M & 59 & $\begin{array}{l}\text { Scarring (old bacterial } \\
\text { keratitis) }\end{array}$ & ++ & 3 & 1 week & Clear \\
\hline 2 & $\mathrm{~F}$ & 64 & Fuchs`dystrophy & - & 0 & 4 days & Clear \\
\hline 3 & $\mathrm{~F}$ & 18 & Herpetic scarring & ++ & 3 & 8 days & Clear \\
\hline 4 & $\mathrm{~F}$ & 67 & Keratoconus & - & 0 & 1 week & Clear \\
\hline 5 & $\mathrm{~F}$ & 68 & Interstitial keratitis & + & 0 & 2 weeks & Clear \\
\hline 6 & M & 37 & $\begin{array}{c}\text { Pellucid marginal } \\
\text { degeneration }\end{array}$ & ++ & 1 & 2 weeks & Rejected \\
\hline 7 & M & 62 & Fuchs' dystrophy & + & 1 & 3 weeks & Rejected \\
\hline 8 & $\mathrm{~F}$ & 24 & Keratoconus & - & 0 & 10 days & Clear \\
\hline 9 & M & 48 & $\begin{array}{l}\text { Scarring (old bacterial } \\
\text { keratitis) }\end{array}$ & ++ & 4 & 3 weeks & Clear \\
\hline 10 & M & 67 & $\begin{array}{l}\text { Scarring (old bacterial } \\
\text { keratitis) }\end{array}$ & ++ & 2 & 3 weeks & Clear \\
\hline
\end{tabular}

Vascularisation: $-=\mathrm{Nil} ;+=$ Mild $(<10$ vessels $) ;++=$ Severe $(10+$ vessels $)$. 
Table II Corneal thickness (microns)

\begin{tabular}{cccc}
\hline Patient no & Pre-rejection & Rejection & 2 months post rejection \\
\hline 1 & 454 & 771 & 474 \\
2 & 537 & $620^{*}$ & 480 \\
3 & 563 & $>1000$ & 592 \\
4 & 560 & 650 & 531 \\
5 & 554 & 799 & 510 \\
6 & 557 & 963 & $690^{* * *}$ \\
7 & 554 & $>1000$ & $>1000^{* * *}$ \\
8 & 462 & $>1000$ & 553 \\
9 & 436 & $530^{*}$ & 413 \\
10 & 438 & 890 & 510 \\
\hline
\end{tabular}

* Corneal rejection line

** Graft failed to clear

rejection episode and the value two months later are recorded, together with the prerejection measurements, in Table II. Both the patients that rejected and whose grafts remained hazy, had very oedematous corneas (963 and >1000 microns) on presentation and had delayed in seeking medical help. All the grafts in which the rejection episode was reversed regained a central graft thickness of less than 600 microns. No complications were encountered with the corticosteroid pulse therapy.

The total white cell count rose during the first two to three days: this was predominantly the result of an increased number of neutrophils. The lymphocyte count was decreased on the day following therapy but this had recovered by the second day (Fig. 1).

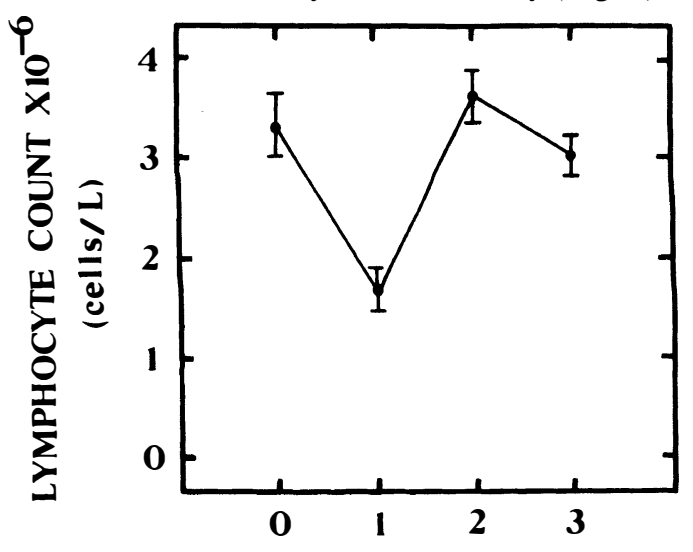

DAY AFTER TREATMENT

Fig. 1. The number of lymphocytes in circulating blood following a single pulse of $500 \mathrm{mg}$ methylprednisolone.

\section{Discussion}

The rejection reversal rate of $80 \%$ compares favourably with other studies in which reversal rates of between $50 \%$ and $76 \%{ }^{10,12-1+}$ were found. The reversal rate also depends on the degree of vascularisation: Fine and Stein ${ }^{19}$ found that $66 \%$ of rejection episodes in avascular corneas cleared but only $50 \%$ in corneas in vascularised beds. Alldredge and Krachmer $^{10}$ reported that $65 \%$ of rejecting grafts in vascularised beds cleared. Seven of our 10 patients had vascularised corneas preoperatively and therefore the results should have been biased towards failure. In addition six patients presented with the rejection having been in progress for more than a week, this is another factor mitigating against successful graft clearing. ${ }^{10}$ Patient number six responded well to treatment initially but the cornea remained hazy with a thickness of 690 microns, despite the eye being quiet with no residual signs of rejection. Had he sought treatment earlier than two weeks it is possible that sufficient endothelial cells to maintain a clear cornea may have survived the rejection attack.

The response of the circulating white blood cells to the pulse of corticosteroid is similar to that reported by authors working in other fields. ${ }^{20}$ The exact mechanism by which intravenous pulse therapy operates is not well understood but may follow the course of events suggested by Meyer et al. ${ }^{16}$ Studies have shown that a transient lymphopenia occurs which is maximal at four to six hours with T lymphocytes being affected to a greater extent than $\mathrm{B}$ cells, and with a relatively 
greater depletion of the helper/inducer subpopulation..$^{21}$ The concentration of lymphocytes returns to normal by 48 hours, a similar pattern was found in our studies. It is thought that the decreased lymphocyte count is due to a change in distribution rather than to cell lysis, ${ }^{21.22}$ although local lymphocyte lysis has been demonstrated when topical corticosteroids are used in corneal graft rejection. ${ }^{23}$ After a single pulse of steroid, delayed hypersensitivity skin tests and primary and secondary antibody responses return to normal by 48 hours: $^{2+}$ at the same time that circulating lymphocytes are restored. However, the antiinflammatory effect lasts four to seven days and it is possible that the clinical effect of pulse therapy is anti-inflammatory and not immunolytic. ${ }^{21}$ A pulse of corticosteroid appears able to 'reset' an aberrant immune response by the simultaneous occurrence of inhibition of the proliferating clone, the temporary removal of recirculating T-lymphocytes from the blood and eye, and the profound suppression of peripheral inflammation. ${ }^{16}$ This immunological manipulation has been shown to induce long term remissions in destructive corneal and scleral disease. ${ }^{16}$ From this small preliminary trial it would appear that pulsed corticosteroid therapy is beneficial in the management of corneal graft rejection and further studies will now be undertaken.

This study was partially supported by a grant from the South African Medical Research Council.

Key words: Corneal graft, rejection, treatment, pulse therapy, corticosteroids.

\section{References}

'Khodadoust AA: The allograft rejection reaction: the leading cause of late failure of clinical corneal grafts. In: Porter R and Knight J, eds: Corneal graft failure, Ciba Foundation Symposium. Amsterdam, Elsevier Publishing Co. 1973, 15: 151-64.

${ }^{2}$ Arentsen JJ: Corneal transplant allograft reaction: possible predisposing factors. Trans Am Ophthalmol Soc 1983, 81: 361-402.

${ }^{3}$ Khodadoust AA and Silverstein AM: Transplantation and rejection of individual cell layers of the cornea. Invest Ophthalmol Vis Sci 1969, 8: 180-95.

${ }^{4}$ Abbott RL, Fine M, Guillet E: Long term changes in corneal endothelium following penetrating keratoplasty: a specular microscopic study. Ohthalmology 1983, 90: 676-85.
${ }^{5}$ Watson AP, Simcock PR, Ridgway AEA. Endothelial cell loss due to repeated traumatic wound dehiscence after penetrating keratoplasty. Cornea 1987, 6: 216-18.

"Smolin G and Goodman D: Corneal graft reaction. Int Ophthalmol Clin 1988, 28: 30-6.

${ }^{7}$ Brooks AMV, Grant G, Gillies WE: Assessment of the corneal endothelium following keratoplasty. Aust NZ J Ophthalmol 1989, 17: 379-85.

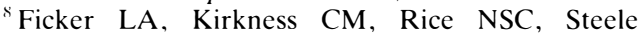
ADMcG: The changing management and improved prognosis for corneal grafting in herpes simplex keratitis. Ophthalmology 1989, 96: 1587-6.

${ }^{9}$ Boisjoly HM, Bernard P, Dube I, Laughrea P, Bazin $\mathrm{R}$, Bernier J: Effect of factors unrelated to tissue matching on corneal transplant endothelial rejection. Am J Ophthalmol 1989, 107: 647-54.

1" Alldredge OC and Krachmer JH: Clinical types of corneal rejection: their manifestations, frequency, preoperative correlates, and treatment. Arch Ophthalmol 1981, 99: 599-604.

"Stulting RD, Waring GO, Bridges WZ, Cavanagh HD: Effect of donor epithelium on corneal transplant survival. Ophthalmology 1988, 95: 803-12.

${ }^{12}$ Gibbs DC, Batchelor JR, Werb A, Schlesinger W, Casey TA: The influence of tissue-type compatibility on the fate of full-thickness corneal grafts. Trans Ophthalmol Soc UK 1974, 94: 101-26.

${ }^{13}$ Chandler JW and Kaufman HE: Graft reactions after keratoplasty for keratoconus. Am J Ophthalmol 1974, 77: 543-7.

${ }^{1+}$ Williams KA, Sawyer MA, White MA, Mahmood MI, Coster DJ: Report from the Australian corneal graft registry. Transplant Proc 1989, 21: 3142-4.

${ }^{15}$ Wakefield D, McCluskey P, Penny R: Intravenous pulse methylprednisolone therapy in severe inflammatory eye disease. Arch Ophthalmol 1986, 104: 847-51.

${ }^{16}$ Meyer PA, Watson PG, Franks W, Dubord P: 'Pulsed' immunosuppressive therapy in the treatment of immunologically induced corneal and scleral disease. Eye 1987, 1: 487-95.

${ }^{17}$ Orta-Sibu N, Chantler C, Bewick M, Haycock G: Comparison of high-dose intravenous methylprednisolone with low-dose oral prednisolone in acute renal allograft rejection in children. $\mathrm{Br}$ Med J 1982, 285: 258-60.

${ }^{18}$ Braude LS and Chandler JW: Corneal allograft rejection. The role of the major histocompatibility complex. Surv Ophthalmol 1983, 27: 290-305.

${ }^{19}$ Fine $\mathrm{M}$ and Stein $\mathrm{M}$ : The role of corneal vascularisation in human corneal graft reactions. In: Porter $\mathrm{R}$ and Knight $\mathrm{J}$, eds: Corneal graft failure, Ciba Foundation Symposium. Amsterdam, Elsevier Publishing Co. 1973, 15: 193-208.

${ }^{20}$ Silverman ED, Myones BL, Miller JJ: Lymphocyte subpopulation alterations induced by intravenous megadose pulse methylprednisolone. J Rheumatol 1984, 11: 287-90.

${ }^{21}$ Haynes BF and Fauci AS: The differential effect of in vivo hydrocortisone on the kinetics of subpopu- 
lations of human peripheral blood thymusderived lymphocytes. J Clin Invest 1978, 61: 703-7.

2 Stevenson HC and Fauci AS: Effects of corticosteroids on the function and distribution of human lymphocytes. In: Franklin EC, ed. Clinical Immunology Update. New York: Elsevier North Holland Inc. 1981, 337-50. 23olack FM: Lymphocyte destruction during corneal homograft reaction: a scanning electron microscope study. Arch Ophthalmol 1973, 89: +13-16.

${ }^{-+}$Fan PT, Yu DTY, Clements PJ, Fowlston S, Eisman $\mathrm{J}$. Bluestone R: Effects of corticosteroids on human immune response: comparison of one and three daily 1 gram intravenous pulses of methylprednisolone. J Lab Clin 1978, 91: 625-34. 